\title{
Thermal Diffusion and Related Phenomena in Cubic (fcc and bcc) Sulfate Lattices
}

\author{
Arnold Lundén and John-Erik Olsson \\ Department of Physics, Chalmers Institute of Technology, Göteborg, Sweden
}

(Z. Naturforsch. 23 a, 2045—2052 [1968] ; received 15 August 1968)

\begin{abstract}
Thermal diffusion of cations has been studied in face-centered cubic $\mathrm{Li}_{2} \mathrm{SO}_{4}$ containing small amounts of other sulfates (temp. range $590-750^{\circ} \mathrm{C}$ ), in body-centered cubic $\mathrm{LiAgSO}_{4}$ containing about $0.5 \%$ of other alkali sulfates $\left(450-550{ }^{\circ} \mathrm{C}\right)$ and in body-centered cubic $\mathrm{LiNaSO}_{4}(546$ to $588^{\circ} \mathrm{C}$ ). For the fcc systems the size of the added cation was of great importance for the thermal diffusion. Thus, for the small $\mathrm{Na}^{+}$and $\mathrm{Ag}^{+}$ions, the Soret-coefficients $(\sigma)$ are of the order of only $10^{-4}$ degr. $^{-1}$. The direction has not been established with certatinty, although there are indications that $\mathrm{Ag}^{+}$, and also $\mathrm{Ca}^{2+}$, are enriched on the cold side, while $\mathrm{Na}^{+}$might be slightly enriched on the hot side. There is a significant enrichment of the large alkali ions $\left(\mathrm{K}^{+}, \mathrm{Rb}^{+}, \mathrm{Cs}^{+}\right)$on the hot side; $\sigma=-2 \times 10^{-3}$ degr. ${ }^{-1}$ for $\mathrm{K}^{+}$. In some experiments with these large alkali ions phase boundaries were intersected, and the large ion was always enriched in the high-temperature phase.

In bcc $\mathrm{Li}_{2} \mathrm{SO}_{4}-\mathrm{Ag}_{2} \mathrm{SO}_{4}$ (containing 40 mole $\% \mathrm{Li}_{2} \mathrm{SO}_{4}$ ) the light component $\mathrm{Li}^{+}$was enriched at the hot side: $\sigma \leqq 1.7 \times 10^{-3}$ degr. ${ }^{-1}$. Regarding added alkali ions, $\mathrm{Na}^{+}$is enriched at the hot side $\left(\sigma \sim 2 \times 10^{-3}\right.$ degr. $^{-1}$ ), while the direction is not established with certainty for $\mathrm{K}^{+}$and $\mathrm{Rb}^{+}$. In bcc $\mathrm{LiNaSO}_{4}$ no significant separation of the two cations could be detected, and the Soret-coefficient is certainly less than $10^{-3}$ degr. ${ }^{-1}$.

A comparison of fcc and bcc sulfates with molten salts regarding thermal diffusion, electromigration mobility of cations, and the conductivity changes caused by impurities, shows a distinction between the fcc systems on one side and bcc sulfates and melts on the other. This supports previous conclusions that the fcc systems are characterised by a higher degree of order than the bec ones.
\end{abstract}

In this laboratory we have been concerned for several years with transport properties of cubic modifications of solid sulfates as well as with thermal diffusion in molten salts and metals. Both these lines of interest were united in our study of the isotope effect for thermal diffusion in fcc lithium sulfate ${ }^{1}$, and as an extension of previous work in both fields we decided to study thermal diffusion of cations in fcc and bcc sulfates. Serious problems at the beginning of this investigation were the lack of diffusion data and reliable phase diagrams for most of the systems to be studied. Recent diffusion measurements ${ }^{2-4}$ and phase diagram determinations ${ }^{5-7}$ simplify the interpretation of the experiments.

\section{Experimental}

In principle, the arrangement is to keep a temperature difference between the top and bottom part of a salt column for some days ${ }^{1}$. The length of the salt col-

1 K. Lindquist and A.LundÉn, Z. Naturforsch. 16 a, 626[1961].

2 A. Kvist and U. Trolle, Z. Naturforsch. 22 a, 213 [1967].

3 A. Kvist and A. Bengtzelius, Z. Naturforsch. 23 a, 679 [1968].

4 A. Bengtzelius, A. Kvist, and U. Trolle, to be submitted to Z. Naturforsch.

5 B. Augustsson and A. Kvist, Z. Naturforsch. 22 a, 1177 [1967].

6 B. Augustsson and J. Gustafsson, Z. Naturforsch. 22 a, 1634 [1967]. umn is about $4 \mathrm{~cm}$. Analytical grade chemicals were used without further purification. A batch of salt of a certain composition was prepared by mixing, melting, quenching and grinding. An amount of salt from such a batch was filled into a Vycor glass cell placed in an auxiliary furnace. While the salt was molten, the cell was moved over to the main furnace, which had been adjusted to the desired temperatures. The salt solidified rapidly, and the initial composition was the same along the whole column ${ }^{8}$. The duration of an experiment was usually of the order of 100 hours, and after quenching, samples from the top and the bottom of the column were analysed by means of atomic absorption or flame emission spectrophotometry ${ }^{9}$.

\section{Definitons and Equations}

The Soret coefficient, $\sigma$, can be defined in several ways, e. g.

$$
\sigma=\frac{1}{N_{\mathrm{H}}\left(1-N_{\mathrm{C}}\right)} \cdot \frac{N_{\mathrm{C}}-N_{\mathrm{H}}}{T_{\mathrm{H}}-T_{\mathrm{C}}}
$$

7 K. Schroeder and A. Kvist, Z. Naturforsch. 23 a, 773 [1968].

8 A couple of check experiments were made where either the salt column was analysed immediately after solidification in a temperature gradient, or the salt was solidified in the auxilliary furnace before being transferred into the gradient.

9 Professor D. Dyrssen, Department of Analytical Chemistry, University of Gothenburg, has kindly placed an atomic absorption spectrophotometer at our disposal. 
where $N$ is the equivalent fraction of the solute cation and $T$ is the temperature, with subscripts $\mathrm{H}$ and $\mathrm{C}$ referring to the hot and cold side, respectively. Some authors prefer to define the thermal diffusion factor, $\alpha$, from the relation ${ }^{10}$

$$
Q=\left(\frac{T_{\mathrm{H}}}{T_{\mathrm{C}}}\right)^{\alpha}
$$

where in our notation

$$
\begin{aligned}
& Q=\frac{1-N_{\mathrm{H}}}{N_{\mathrm{H}}} \cdot \frac{N_{\mathrm{C}}}{1-N_{\mathrm{C}}}, \\
& \alpha=\sigma T .
\end{aligned}
$$

In all our experiments $\Delta T=T_{\mathrm{H}}-T_{C}$ is less than $20 \%$ of $T_{\mathrm{H}}$, so we have approximately

$$
\sigma=\ln Q / \Delta T \text {. }
$$

If $Q$ is close to unity, (5) is approximately equal to (1). Although the choice between using (1) or (5) is, in principle, a matter of convention, Soret coefficients estimated from (5) are more sensitive to the accuracy of the chemical analysis for cases when the concentration of the solute becomes very small at the cold side. We thus prefer to use (1) as the definition of $\sigma$. This is in agreement with our previous practice ${ }^{11}$.

In some experiments (those with bcc $\mathrm{LiAgSO}_{4}$ ) there were more than two cation species. For ions present in minor concentrations we define the Soret coefficient as

$$
\sigma(\mathrm{i})=\frac{1}{N_{\mathrm{H}}^{1}\left(1-N_{\mathrm{H}}^{1}\right)} \frac{N_{\mathrm{H}}^{1}-N_{\mathrm{C}}^{\mathrm{A}}}{T_{\mathrm{H}}-T_{\mathrm{C}}} .
$$

The two terms in the numerator are reversed in comparison with Eq. (1), since the sign convention is that $\sigma$ is the positive when a light component is enriched on the hot side, and $\mathrm{Li}_{2} \mathrm{SO}_{4}$ is the solvent in all cases when Eq. (1) is used, but $\mathrm{Ag}_{2} \mathrm{SO}_{4}$ is considered as the solvent for the ternary mixtures.

A further entity is the heat of transport, $Q^{*}$, which is of basic importance for interpreting thermal diffusion experiments by means of theories based upon the thermodynamics of irreversible processes. The original relationship between $Q^{*}$ and $\alpha$ requires knowledge of chemical potentials ${ }^{12}$. However, for convenience, "apparent heats of transport" are defined by means of the steady state concentration

10 W. Jost, Diffusion in Solids, Liquids, Gases. Academic Press, New York 1960, p. 494.

11 V. Backlund, J. Dupuy, S. Gustafsson, and A. Lundén, Z. Naturforsch. 22 a, 471 [1967].

12 Cf. e. g. K. F. Alexander, Fortschr. Phys. 8, 1 [1960]. gradient ${ }^{13}$. The relation between the apparent heat of transport, $Q_{\mathrm{app}}^{\star}$ and the Soret coefficient is

$$
Q_{\text {app }}^{*}=-R \sigma T^{2}
$$

where $R=$ the gas constant.

The sign convention is that the heat of transport is positive for a component that is enriched on the cold side.

The thermal diffusion coefficient, $D^{\prime}$, is defined as $D^{\prime}=\sigma D$, where $D$ is the (isothermal) diffusion coefficient of the species in question. For a comparison of different transport properties we shall introduce a thermal diffusion transport rate (e.g. moles $/ \mathrm{cm}^{2} \mathrm{~s}$ ), which for a given temperature gradient, is proportional to $D^{\prime} c$, where $c$ is the concentration $\left(\operatorname{moles} / \mathrm{cm}^{3}\right)$ of the component in question.

Since we now are giving a report on obtained results, without attempts to quantitative interpretations, only the Soret coefficients will, in general, be given in this paper.

In the definition of the Soret coefficient the concentrations $N_{\mathrm{H}}$ and $N_{\mathrm{C}}$ correspond to the steady state. The approach to this state follows approximately the relation ${ }^{\mathbf{1 4}}$

$$
\sigma_{\mathrm{t}}=\sigma[1-\exp (-t / \Theta)]
$$

where we shall call $\sigma_{\mathrm{t}}$ the transient Soret coefficient, which is calculated by inserting the concentrations at the time $t$ in Eq. (1) or (6). $\Theta$ is called the characteristic time, and it depends on the height of the cell $h$ and the diffusion coefficient $D$. If one of the reservoirs has an infinite volume the characteristic time can be estimated as

$$
\Theta=4 h^{2} / \pi^{2} D \text {. }
$$

If, instead, the volumes of both reservoirs are negligible:

$$
\sigma=h^{2} / \pi^{2} D
$$

\section{Results}

For most experiments the duration is about 100 hours. This time was chosen on the basis of an early determination of the self-diffusion coefficient of $\mathrm{Li}^{+}$in lithium sulfate ${ }^{15}$. The actually measured, transient Soret coefficients, $\sigma_{t}$, will be report-

13 A. R. Allnatt and A. V. Chadwick, Chem. Rev. 67, 681 [1967].

14 H. J. V. Tyrrell, Diffusion and Heat Flow in Liquids, Butterworths, London 1961, p. 195.

15 A. LundÉn, Z. Naturforsch. 17 a, 142 [1962]. 
ed here. For nearly all the systems considered here, diffusion coefficients are now available ${ }^{2-4}$, although most of them have been measured at somewhat different concentrations than the thermal diffusion experiments have been done at, e. g. the diffusion of impurities in fcc- $\mathrm{Li}_{2} \mathrm{SO}_{4}$ has been studied at very low concentrations.

More than 60 cells were investigated, usually with similar conditions for some $2-4$ cells, see Tables $1-3$, where the results are presented. For each group average values are given for the temperatures $\left(T_{\mathrm{H}}, T_{\mathrm{C}}\right)$, duration $(t)$ and usually also the concentrations $\left(N_{\mathrm{H}}, N_{\mathrm{C}}\right)$. However, in a few groups the concentrations were spread over the ranges quoted in the tables.

Table 1 contains those experiments with monovalent ions for which it is evident from the phase diagrams ${ }^{5,6,16}$ that the whole cell was held within the same phase. For $\mathrm{Ag}^{+}$and $\mathrm{Na}^{+}$it is not certain that thermal diffusion has caused any changes in concentration, although there is an indication that $\mathrm{Ag}$ has been enriched at the cold side, and that $\mathrm{Na}$ might have been so towards the hot side. The Soret coefficients for these two ions are of the order of $10^{-4}$ degr. $^{-1}$ or perhaps less. The large alkali ions $\mathrm{K}^{+}, \mathrm{Rb}^{+}$, and $\mathrm{Cs}^{+}$become enriched at the hot side. (For $\mathrm{Cs}^{+}$the evidence of this is not as clear, since phase boundaries were intersected in all experiments with this ion, see below.) For $\mathrm{K}^{+}$the Soret coeffi- cient is approximately $\sigma=-2 \times 10^{-3} \mathrm{degr}^{-1}$, and it might be of the same magnitude for $\mathrm{Rb}^{+}$.

Regarding the system $\mathrm{Li}_{2} \mathrm{SO}_{4}-\mathrm{CaSO}_{4}$, it might be expected from MüLLER's phase diagram ${ }^{17}$. (A more recent one gives only the liquidus curve ${ }^{18}$ ) that the samples taken at the top of our column correspond to a two-phase region, but on the other hand conductivity measurements indicate that other divalent ions $\left(\mathrm{Mg}^{2+}, \mathrm{Cd}^{2+}, \mathrm{Ba}^{2+}\right)$ are soluble in lithium sulfate ${ }^{19}$, and the ionic radius is about the some for $\mathrm{Ca}^{2+}$ as for $\mathrm{Na}^{+}$. Thus, we assume that also the experiment with $\mathrm{Ca}^{2+}$ corresponds to a single phase.

There are three possible cation positions in the fcc sulfate lattice: two tetrahedral, and one octahedral. The space available in these positions depends on the spatial orientation of the sulfate ions (l. c. ${ }^{20,21}$ ). However, the free space at an octahedral position is always considerably larger than at the tetrahedral ones. If the small Li-ions are gradually replaced by other, larger ions, which only can fit into octahedral positions, we can expect that this influences the sulfate lattice. This effect should become stronger, the larger the radius of the added cation is. It has also been found that the mechanical properties of the salt (measured as an apparent viscosity) change drastically, when the concentration of $\mathrm{K}^{+}, \mathrm{Rb}^{+}$or $\mathrm{Cs}^{+}$exceeds a certain limit ${ }^{5}$, while this transition does not occur when $\mathrm{Na}^{+}$is added.

\begin{tabular}{|c|c|c|c|c|c|c|c|}
\hline \multirow{2}{*}{$\begin{array}{l}\text { Added } \\
\text { ion } \\
\mathbf{M}\end{array}$} & \multirow{2}{*}{$\begin{array}{l}\text { Conc. } \\
100 \mathrm{~N}_{\mathrm{H}} \\
\%\end{array}$} & \multicolumn{2}{|c|}{ Temperature } & \multirow{2}{*}{$\begin{array}{l}\text { Duration } \\
\text { hours }\end{array}$} & \multirow{2}{*}{$\begin{array}{c}\text { Number } \\
\text { of } \\
\text { cells }\end{array}$} & \multirow{2}{*}{$\begin{array}{c}\text { Soret coefficient } \\
\text { measured } \\
\sigma_{\mathrm{t}} \times 10^{3} \\
\text { degr. }{ }^{-1}\end{array}$} & \multirow{2}{*}{$\begin{array}{c}\sigma_{\mathrm{t}} / \sigma \\
\%\end{array}$} \\
\hline & & $\begin{array}{c}\text { top } \\
{ }^{\circ} \mathrm{C}\end{array}$ & $\begin{array}{c}\text { bottom } \\
{ }^{\circ} \mathrm{C}\end{array}$ & & & & \\
\hline $\mathrm{Ag}$ & $4-5$ & 743 & 586 & 98 & 5 & $0.18 \pm 0.23$ & 67 \\
\hline $\mathrm{Na}$ & 1.9 & 752 & 593 & 95 & 4 & $-0.33 \pm 0.32$ & 77 \\
\hline $\mathrm{Na}$ & 7.6 & 748 & 596 & 96 & 4 & $0.09 \pm 0.70$ & 77 \\
\hline $\mathrm{K}$ & $0.6-1.2$ & 738 & 604 & 95 & 3 & $-1.35 \pm 0.08$ & 60 \\
\hline $\mathrm{K}$ & 0.5 & 738 & 611 & 192 & 2 & $-1.57 \pm 0.30$ & 85 \\
\hline $\mathrm{Rb}$ & 0.7 & 737 & 603 & 96 & 3 & $-0.89 \pm 0.37$ & 43 \\
\hline $\mathrm{Rb}$ & 0.6 & 739 & 611 & 192 & 2 & $-0.01 \pm 0.14$ & 68 \\
\hline $\mathrm{Ca}$ & 2.4 & 748 & 594 & 96 & 2 & $0.90 \pm 0.33$ & 17 \\
\hline
\end{tabular}

Table 1. Thermal diffusion in a single phase of solid solutions of $\mathrm{M}_{2} \mathrm{SO}_{4}\left(\mathrm{M}=\mathrm{Ag}, \mathrm{Na}, \mathrm{K}, \mathrm{Rb}\right.$; also CaSO $\mathrm{Cin} \mathrm{LiSO}_{4}$. The quoted temperatures $\left(T_{\mathrm{H}}\right.$ and $\left.T_{\mathrm{C}}\right)$ and durations are averages for the group of cells. The concentration $N_{\mathrm{H}}$ is also averaged, except when the quoted concentration range was covered. The 192-hour cells were analysed twice, all others only once. The transient Soret coefficient, $\sigma_{\mathrm{t}}$, is calculated from Eq. (1), and the quoted errors are standard deviations of the mean. The ratio $\sigma_{\mathrm{t}} / \sigma$, Eq. (8), is calculated for the case that the reservoir is of infinite size, Eq. (9). The experiments with $\mathrm{CaSO}_{4}$ are included in this table although it is not proved that they correspond to a single phase.

16 H. A. ØуЕ, Acta Chem. Scand. 18, 361 [1964].

17 H. Müller, N. Jb. Min. Beilagebd. 30, 45 [1910].

18 M. S. Golubeva and A. G. Bergman, Zh. Obshch. Khim. 24, 1940 [1954].
19 A. Kvist, Thesis, Göteborg 1967.

20 T. Forland and J. Krogh-Moe, Acta Chem. Scand. 11, 565 [1957].

21 H. A. Ø 
Fig. 1 shows a schematic phase diagram based on differential thermal analysis, and on conductivity and viscosity measurements. A definite interpretation of the different phases would require X-ray and probably still other investigations. Tentatively,

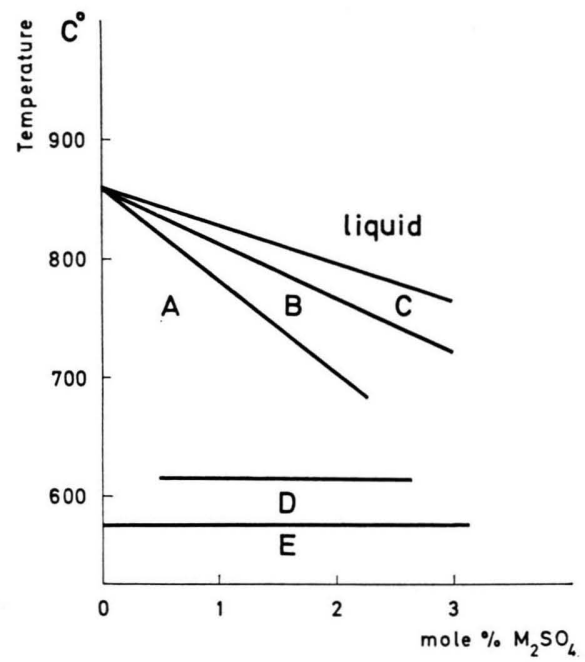

Fig. 1. Schematic phase diagram for the system $\mathrm{Li}_{2} \mathrm{SO}_{4}-\mathrm{M}_{2} \mathrm{SO}_{4}$. The probable composition in the different regions is discussed in the text.

A represents a phase isomorphous to $\alpha-\mathrm{Li}_{2} \mathrm{SO}_{4}$, and $\mathrm{C}$ is a two-phase (solid-liquid) region. The transition from $\mathrm{A}$ to $\mathrm{B}$ corresponds to the mentioned change in mechanical properties. Finally, the transition from A to D has only been found for $\mathrm{Cs}^{+}$(at $615{ }^{\circ} \mathrm{C}$ ). Table 2 contains the cells for which one or more phase boundaries were intersected. As can be seen from the three cells which were taken out al- ready after $10-15 \mathrm{~min}$ the initial concentration was, at least approximately, the same along the whole column. The four $\mathrm{Rb}^{+}$-cells with times ranging from $10 \mathrm{~min}$ to 198 hours (lines 5-8 in Table 2) were analysed along their whole length (while only top and bottom samples were analysed for most other cells), and it was evident for the 99 and 198 hour cells, that there were two regions which differed very much regarding the concentration of $\mathrm{Rb}^{+}$. The transition between the two regions appeared to be fairly sharp, while the concentration was about the same within a region. For cells containing $\mathrm{Cs}^{+}$ the composition of the bottom sample depends on whether this sample was situated above or below the $\mathrm{A}-\mathrm{D}$ transition (lines 9 and 10). The present experiments thus give further support to the existence of the phase transitions detected by other methods. As a general rule, the added, large, ions are enriched in the high-temperature region. A formal calculation of a Soret coefficient gives $(-2.2 \pm 0.8)$ $\times 10^{-3}$ degr. $^{-1}$ for the quoted $\mathrm{K}^{+}$experiments (line 1) and much higher values for $\mathrm{Rb}^{+}$and $\mathrm{Cs}^{+}$. However, since phase boundaries are intersected, the transport process is not thermal diffusion. It might be mentioned in this conection that the considerable separation effects observed by ReinHold in some solid ionic crystals have been reinterpreted as being due not to thermal diffusion but instead to the fact that the hot and cold parts belonged to different phases ${ }^{22}$.

For bcc $(\mathrm{Li}, \mathrm{Ag})_{2} \mathrm{SO}_{4}$ transient Soret coefficients were calculated for the main constituents, an added amount of about $\frac{1}{2} \%$ of another alkali ion and also

\begin{tabular}{|c|c|c|c|c|c|c|c|c|}
\hline \multirow{3}{*}{$\begin{array}{c}\text { Added } \\
\text { ion } \\
\text { M }\end{array}$} & \multicolumn{2}{|c|}{ Conc. } & \multicolumn{2}{|c|}{ Temperature } & \multirow{3}{*}{$\begin{array}{l}\text { Duration } \\
\text { hours }\end{array}$} & \multirow{3}{*}{$\begin{array}{l}\text { Number } \\
\text { of cells }\end{array}$} & \multirow{2}{*}{\multicolumn{2}{|c|}{$\begin{array}{l}\text { Probable region } \\
\text { in phase diagram }\end{array}$}} \\
\hline & top & bottom & top & bottom & & & & \\
\hline & $\begin{array}{c}100 N_{\mathrm{H}} \\
\%\end{array}$ & $\begin{array}{c}100 N_{\mathrm{C}} \\
\%\end{array}$ & ${ }^{\circ} \mathrm{C}$ & ${ }^{\circ} \mathrm{C}$ & & & top & bottom \\
\hline $\mathrm{K}$ & 2.8 & 1.8 & 751 & 595 & 100 & 2 & $\mathrm{C}(\mathrm{B}$ ?) & A \\
\hline $\mathrm{Rb}$ & 4.3 & 0.6 & 750 & 595 & 92 & 2 & $\mathrm{C}^{\prime}$ & A \\
\hline $\mathrm{Rb}$ & 5.3 & 0.8 & 750 & 651 & 97 & 4 & $\mathrm{C}$ & $\mathrm{A}$ \\
\hline $\mathrm{Rb}$ & 3.7 & 2.4 & 746 & 652 & $1 / 4$ & 1 & $\mathrm{C}$ & B \\
\hline $\mathrm{Rb}$ & 5.2 & 5.5 & 746 & 606 & $1 / 6$ & 1 & $\mathrm{C}$ & $\mathrm{C}$ \\
\hline $\mathrm{Rb}$ & 5.8 & 1.8 & 748 & 610 & 50 & 1 & $\mathrm{C}$ & A \\
\hline $\mathrm{Rb}$ & 5.5 & 1.9 & 748 & 603 & 99 & 1 & $\mathrm{C}$ & $\mathrm{A}$ \\
\hline $\mathrm{Rb}$ & 6.8 & 1.0 & 748 & 600 & 198 & 1 & $\mathrm{C}$ & A \\
\hline Cs & $0.8-4.0$ & 0 & 740 & 604 & 95 & 3 & $\mathrm{~A}, \mathrm{~B}, \mathrm{C}$ & D \\
\hline Cs & 5.2 & 0.5 & 752 & 652 & 97 & 4 & $\mathrm{C}$ & $\mathrm{A}$ \\
\hline Cs & 2.1 & 2.4 & 746 & 652 & $1 / 6$ & 1 & B & $\mathrm{B}(\mathrm{A}$ ?) \\
\hline
\end{tabular}

Table 2. Effect of temperature gradient on the composition of $(\mathrm{Li}, \mathrm{M}){ }_{2} \mathrm{SO}_{4}$ in cases where phase boundaries are intersected. Regarding the symbols A, B, C and D, see Fig. 1.

22 Cf. cit. ${ }^{10}$, p. 526. 


\begin{tabular}{|c|c|c|c|c|c|c|c|}
\hline \multicolumn{4}{|c|}{$\begin{array}{c}\text { Composition }\left(100 N_{\mathrm{H}}\right) \\
\text { mole } \%\end{array}$} & \multicolumn{4}{|c|}{$\begin{array}{l}\text { Transient Soret coefficients } \\
\qquad \sigma_{\mathrm{t}} \times 10^{-3} \text { degr. }^{-1}\end{array}$} \\
\hline $\mathrm{Li}$ & $\mathrm{Na}$ & $\mathbf{K}$ & $\mathrm{Rb}$ & $\mathrm{Li}$ & $\mathrm{Na}$ & $\mathbf{K}$ & $\mathrm{Rb}$ \\
\hline 40.3 & 0.48 & 0.04 & 0 & $0.71 \pm 0.13$ & $1.07 \pm 0.30$ & $-2.41 \pm 2.13$ & - \\
\hline 40.8 & 0.11 & 0.60 & 0 & $0.54 \pm 0.18$ & $1.69 \pm 1.42$ & $0.40 \pm 0.41$ & - \\
\hline 41.6 & 0.06 & 0.05 & 0.46 & $0.71 \pm 0.09$ & $0.11 \pm 2.05$ & $-0.42 \pm 0.80$ & $-0.18 \pm 0.14$ \\
\hline
\end{tabular}

Table 3. Thermal diffusion in bcc $(\mathrm{Li}, \mathrm{Ag})_{2} \mathrm{SO}_{4}$ containing minor amounts of other alkali sulfates. Four cells were investigated for each mixture. The temperature was about $548{ }^{\circ} \mathrm{C}$ at the top and $452{ }^{\circ} \mathrm{C}$ at the bottom. The diffusion time $(t)$ was 142 hours. The quoted errors are standard deviations of the mean.

for impurities (Table 3). The results for the impurities are to be considered as qualitative, both since the accuracy of the analysis is low, and since impurities might in part have been introduced during the experiment due to reactions between the salt and the glass cell. Self-diffusion coefficients of the two cations of $\mathrm{LiAgSO}_{4}$ have been measured recently ${ }^{4}$. $D_{\mathrm{Li}}$ and $D_{\mathrm{Ag}}$ coincide within experimental error, being about $0.63 \times 10^{-5} \mathrm{~cm}^{2} \mathrm{~s}^{-1}$ at $500{ }^{\circ} \mathrm{C}$, and we can assume that the diffusion coefficient of impurity $\mathrm{Na}^{+}$does not differ much from those measured for the main constituents. As an average for all 12 cells we obtain $\sigma_{\mathrm{t}}(\mathrm{Li})=(0.65 \pm 0.07) \times 10^{-3}$ degr. $^{-1}$, while we shall only consider the cells with $0.5 \% \mathrm{Na}$ for $\sigma_{t}(\mathrm{Na})$. Depending on whether the reservoir is considered as infinitive, Eq. (9), or negligible we obtain the following limits for the Soret coefficients:

$$
0.8<\sigma_{\mathrm{Li}} \times 10^{3}<1.7
$$

and

$$
1.2<\sigma_{\mathrm{Na}} \times 10^{3}<2.7 \text {. }
$$

While the enrichment of $\mathrm{Li}$ and $\mathrm{Na}$ on the hot side is significant, the direction is not established with

\begin{tabular}{|c|c|c|c|c|c|}
\hline & $\alpha-\mathrm{Li}_{2} \mathrm{SO}_{4}$ & bcc $(\mathrm{Li}, \mathrm{Ag})_{2} \mathrm{SO}_{4}$ & molten sulfates & molten nitrates & Ref. \\
\hline $\begin{array}{l}\text { Thermal diffusion } \\
\text { transport rate } \\
\text { ( } \sigma \text { or } \sigma N \text { compared) }\end{array}$ & $\begin{array}{l}\mathrm{Li} \cong \mathrm{Na} \cong \mathrm{Ag} \\
\mathrm{Rb} \cong \mathrm{K}>\mathrm{Li} \\
\mathrm{Li}>\mathrm{Ca}\end{array}$ & $\mathrm{Li}>\mathrm{Na}>\mathrm{Ag}$ & & $\begin{array}{l}\mathrm{Li}>\mathrm{K}>\mathrm{Rb} \cong \mathrm{Cs}>\mathrm{Ag} \\
\mathrm{Li}>\mathrm{Rb}\end{array}$ & $23,11,24$ \\
\hline $\begin{array}{l}\text { (Isothermal) } \\
\text { diffusion coefficient }\end{array}$ & $\begin{aligned} \mathrm{Li} & >\mathrm{Na}>\mathrm{Ag}>\mathrm{K}> \\
& >\mathrm{Rb}>\mathrm{Cs}\end{aligned}$ & $\mathrm{Li}=\mathrm{Ag}>\mathrm{K}$ & & $\underset{\text { (pure salts) }}{\mathrm{Li}} \underset{\mathrm{Ag}}{\mathrm{Na}}>\mathrm{K}>\mathrm{Cs}$ & $3,4,25$ \\
\hline $\begin{array}{l}\text { Conductivity of } \\
\text { pure salts }\end{array}$ & & & $\mathrm{Li}>\mathrm{Na}>\mathrm{Ag}>\mathrm{K}>\mathrm{Rb}>\mathrm{Cs}$ & $\mathrm{Ag}>\mathrm{Li}>\mathrm{Na}>\mathrm{K}>\mathrm{Rb}>\mathrm{Cs}$ & 26,27 \\
\hline $\begin{array}{l}\text { Ion mobility (from } \\
\text { electromigration or } \\
\text { transport number } \\
\text { studies) }\end{array}$ & $\begin{array}{l}\mathrm{K}>\mathrm{Li}(9 \% \mathrm{~K}) \\
\mathrm{Ag}>\mathrm{Li}(7 \% \mathrm{Ag}) \\
\mathrm{Ag}>\mathrm{Li}(10-20 \% \\
\mathrm{Ag})\end{array}$ & $\mathrm{Li} \cong \mathrm{Ag}$ & $\begin{array}{l}\mathrm{Li}>\mathrm{K}(\text { for }>50 \% \mathrm{Li}) \\
\mathrm{Li}>\mathrm{Ag}(\text { for }>65 \% \mathrm{Li}) \\
\mathrm{Li} \cong \mathrm{Ag}(\text { for } \sim 50 \% \mathrm{Li})\end{array}$ & loc. cit. 30 & 28,29 \\
\hline $\begin{array}{l}\text { Conductivity charge } \\
\text { caused by impurity } \\
\text { cations in } \mathrm{Li}_{2} \mathrm{SO}_{4}\end{array}$ & $\begin{array}{l}\mathrm{Rb}>\mathrm{Cs}>\mathrm{K}>\mathrm{Li}> \\
\quad>\mathrm{Na} \\
\text { (for } \geqq 1 \% \text { addition) } \\
\mathrm{Li}>\mathrm{K} \text { (for } \\
\cong 0.5 \% \text { addition) }\end{array}$ & $\mathrm{Li} \cong \mathrm{Ag}>\mathrm{K}$ & $\mathrm{Li}>\mathrm{Na}>\mathrm{K}>\mathrm{Rb}>\mathrm{Cs}$ & & $19,31,32$ \\
\hline
\end{tabular}
certainty for $\mathrm{K}$ and $\mathrm{Rb}$, although there is an indica-

Table 4. A compilation of some transport properties for different classes of solid and molten salts. Due to the considerable difference in melting points and decomposition temperatures of the considered salts, it was not always possible to make the comparison at a common temperature, but for two adjacent salts, e. g. $\mathrm{AgNO}_{3}$ and $\mathrm{LiNO}_{3}$, the temperature ranges covered by the measurements always overlapped to some extent.

23 This investigation.

24 S. Gustafsson, Z. Naturforsch. 18 a, 949 [1963] ; 21 a, 842 [1966].

25 A. S. Dworkin, R. B. Escue, and E. R. van Artsdalen, J. Phys. Chem. 64, 872 [1960].

26 A. Kvist, Z. Naturforsch. 22 a, 467 [1967].

27 G. J. Janz, F. W. Dampier, and P. K. Lorenz, Molten Salts: Electrical Conductance, Density and Viscosity Data. Technical Report. Rensselaer Polytechnic Institute, Troy, N.Y. 1966.
28 V. Lubimov and A. Lundén, Z. Naturforsch. 21 a, 1592 [1966].

29 H. A. ØуЕ, Acta Chem. Scand. 21, 111 [1967].

30 A great number of investigations of ion mobilities in nitrate (and halide) mixtures have been performed in recent years. A general observation is that the mobility of a diluted ion is depressed, which occurs whether its radius is larger or smaller than the radius of the abundant ion.

31 A. Kvist, unpublished.

32 A. Kvist, Z. Naturforsch. 21 a, 1601 [1966]. 
tion that $\mathrm{K}^{+}$is enriched on the hot, and $\mathrm{Rb}^{+}$on the cold side.

Four cells with $\mathrm{LiNaSO}_{4}$ were investigated:

$$
T_{\mathrm{H}}=588{ }^{\circ} \mathrm{C} \quad \text { and } \quad T_{\mathrm{C}}=546^{\circ} \mathrm{C} \text {. }
$$

The duration of the experiments ranged from 96 to 240 hours. For these cells the column was divided into eight samples, which all were analysed. It was not possible to say for certain if a separation of the two cations had occurred, and we concluded that $1 \times 10^{-3}$ degr. $^{-1}$ should be considered as the upper limit of the Soret coefficient.

\section{Discussion}

The apparent heat of transport is rather small in most of the systems. Thus it is of the order of 0.2 $\mathrm{kcal} /$ equivalent for $\mathrm{Na}$ and $\mathrm{Ag}$ in fcc- $\mathrm{Li}_{2} \mathrm{SO}_{4}$, i. e. about the same as for the isotope effect studied previously ${ }^{1}$. For $\mathrm{K}^{+}$in fcc- $\mathrm{Li}_{2} \mathrm{SO}_{4}$ it is about $3.6 \mathrm{kcal}$ per equivalent, which is comparable with typical results for e.g. impurities (substitutional as well as interstitial) in metals ${ }^{13}$.

In Table 4 some transport properties are compared for solid (fcc and bcc) and molten sulfates and molten nitrates. Regarding the thermal diffusion transport rate, which is proportional to $D^{\prime}$, see above, we shall neglect the fact that the diffusion coefficient $D$ is not the same for each cation in a considered phase, and for simplicity the Soret coefficients will be compared for the fcc phase and the melt, while $\sigma N$ is compared for the bcc phase. When comparing two species the thermal diffusion transport rate is considered to be largest for the one that is enriched on the hot side. Regarding the electrotransport data in Table 4, the equivalent conductivity, $A$, is given for pure salts, while for mixtures relative ion mobilities have been obtained in two ways. Thus, direct measurements of ion mobilities ${ }^{28,30}$ and transport numbers ${ }^{29}$ are quoted when available. In addition, conductivity data is used, for

33 J. Krogh-Moe, Selected Topics in High-Temperature Chemistry (Ed. T. Førland et al.), Universitetsforlaget, Oslo 1966, p. 79.

34 B. B. Owens and G. R. Argue, Science 157, 308 [1967].

35 S. GELLER, Science 157, 310 [1967].

36 The experimental accuracy was not sufficient to check whether the direction of thermal diffusion might the reversed at very low concentrations. which it is assumed as a first approximation, that the mobilities of the different ionic species are not affected by a small change in concentration ${ }^{19,31,32}$. E. g. this means that the mobility of the added cation is higher than that of $\mathrm{Li}^{+}$, if the conductivity is higher in the mixture than in pure $\mathrm{Li}_{2} \mathrm{SO}_{4}$.

In addition to the sulfate systems discussed here, other examples of cubic structures with a high degree of ionic conductivity are known ${ }^{33-35}$. Of these, those with a bcc lattice seem to have a higher degree of disorder than the fcc ones ${ }^{33}$. It is thus not surprising that there is a difference regarding the direction of thermal diffusion between fcc sulfate systems on one side, and bcc sulfate and molten salts on the other side, and that the fcc phase also differs from the two other phases when the conductivity is considered. Thus $\mathrm{Rb}$ and $\mathrm{K}$ that tend to enrich at the hot side in the fcc phase, cause an increase in the electrical conductivity if their concentration exceeds a critical limit. However, the fact that, when $\mathrm{K}_{2} \mathrm{SO}_{4}$ is added, the effect of impurities on conductivity reverses its sign somewhere between 0.75 and 1.0 mole $\%$, indicates a fundamental difference in the mechanism of electro- and thermal transport ${ }^{36-38}$. The third type of measurements for which a change of sign is found when going from the fcc solid to the melt is direct ion mobility determinations. Thus, both from electromigration experiments ${ }^{28}$ and transport number studies ${ }^{29}$, it is found that the heavy ion $\left(\mathrm{K}^{+}\right.$or $\left.\mathrm{Ag}^{+}\right)$has a higher mobility than $\mathrm{Li}^{+}$in the fcc phase, while the reverse is found for melts with (nearly) the same concentration. In the medium concentration range the $\mathrm{Li}^{+}$ion has nearly the same mobility as the $\mathrm{Ag}^{+}$ion in the solid (bcc $\mathrm{LiAgSO}_{4}$ ) as well as in the melt ${ }^{29}$; it appears as if the more abundant ion has the higher mobility in both phases, i. e. that there is no change in relative mobility when the bcc sulfate melts. (This latter statement is made with some reservations for mixtures with less than about $45 \% \mathrm{Ag}_{2} \mathrm{SO}_{4}$, c. f. cit. ${ }^{29}$.)

37 R. Mills and P.L. Spedding, J. Phys. Chem. 70, 4077 [1966], conclude from the fact that the electrical conductivity and the self diffusion coefficients of molten alkali carbonates show a different temperature dependence, that the mechanisms of the two transport processes are not the same for these systems.

38 A. Lodding, Phys. Stat. Sol. 22, 157 [1967], has recently discussed the consequences that the existence of different transport mechanisms for ion conductivity and diffusion have upon the interpretation of isotope thermal diffusion experiments. 
Considering thermal diffusion in the bcc and molten phases, the light component is enriched on the hot side. (The transport direction for $\mathrm{K}^{+}$and $\mathrm{Rb}^{+}$in the bcc phase is uncertain, see above.) This direction $(\sigma>0)$ is the most common one for thermal transport in binary solid, liquid or gas mixtures ${ }^{13,39,40}$, although transport in the opposite direction $(\sigma<0)$ can also be explained. The Soret coefficient is always found to be positive for isotope effects, including solid and molten salts ${ }^{1,11,24}$ and solid and molten metals ${ }^{41,42}$. While a sufficient agreement regarding sign and magnitude often has been found between experimental and calculated Soret coefficients, there are discrepancies in other cases. For condensed phases, i. e. mainly liquids, each of the proposed models seem to have been applied to only one class of liquids (molten metals, aqueous electrolytes, organic liquids, etc.) for which it has been sought for a correlation between thermal diffusion and some other physical property (such as activation energy of viscous flow); it is not possible as yet to check whether any of these previously used correlations might hold also for solid sulfates. On the other hand the compilation in Table 4 might suggest a correlation between thermal transport and electrotransport for solid and molten salts, but such a correlation does not exist for some molten alloys for which both thermal diffusion and electromigration have been studied ${ }^{43,44}$.

For the $\mathrm{Li}_{2} \mathrm{SO}_{4}$-rich (fcc) phase, diffusion and conductivity measurements support the view that the $\mathrm{Li}^{+}$-ions normally are situated in tetrahedral positions, and that most of the octahedral positions are vacant ${ }^{19}$. Two features of this model are that the $\mathrm{Li}^{+}$ions are placed in positions where the available space is relatively close to the estimated ion volume, and that a symmetrical cation distribution (relative to the anion lattice) is obtained. It might be worth noting that a symmetrical distribution is maintained if two $\mathrm{Li}^{+}$-ions share an octahedral position, leaving both of the tetrahedral positions vacant, but that this possibility does not exist for larger cations. In

${ }^{39}$ Cit. ${ }^{10}$,p. $489-532$; A $78-$ A 82.

40 Cit. ${ }^{14}$, pp. $230-290$.

41 P. Thernquist and A. Lodding, Z. Naturforsch. 22 a, 837 [1967].

42 L. Löwenberg, A. Nordén-Ott, and A. Lodding, Z. Naturforsch. 23 a, 1771 [1968].

43 F. Winter and H. G. Drickamer, J. Phys. Chem. 59, 1229 [1955]. pure $\mathrm{Li}_{2} \mathrm{SO}_{4}$ the number of "thermal defects", i. e. cations in octahedral positions and corresponding vacancies in the lattice of tetrahedral positions, is small, but it should increase if ions are added that are so large that they only fit in octahedral positions. As a qualitative understanding of the migration of large impurity ions to the hot side, it might be said that a mixture with a given number of large cations deviates less from the equilibrium distribution of ions between tetrahedral and octahedral positions, the higher the temperature is. It is possible that this argument can be extended to explain the fact that the large cations tend to concentrate in high temperature (solid or liquid) phases, i. e. the least ordered phase, for the experiments where phase boundaries were intersected, cf. the discussion of Table 2 above. The present investigation of thermal transport concerns the displacement of a cation species relative to another one, which was also the case in the previous investigation of the isotope effect ${ }^{1}$. Another possible effect of a temperature gradient is a displacement of the cations in bulk relative to the anions, and an observed change in the thermoelectric power of pure $\mathrm{Li}_{2} \mathrm{SO}_{4}$ has been interpreted as due to a net migration of cations towards the cold side ${ }^{45}$.

Since we are considering a model with vacancies in the tetrahedral positions and "interstitial" ions in octahedral positions, it is of interest to make a brief comparison with other recent studies of thermal diffusion of interstitials or vacancies in solid systems. Allnatr and Chadwick have derived a theory for thermal diffusion of substitutional or interstitial impurities in ionic crystals ${ }^{46}$. Considerable interest has been devoted to thermal diffusion of interstitially dissolved impurities $(\mathrm{H}, \mathrm{C}, \mathrm{N}, \mathrm{O})$ in metals ${ }^{13,47}$ and to thermal diffusion of substitutional impurities in fcc metal crystals ${ }^{13}$. The theoretical interpretation of these experiments in metals has advanced considerably in recent years, cf. recent reviews of the field ${ }^{13}$. Characteristic for all theories of thermal diffusion in solids is that the heat of transport for

44 J. Angus, J. Verhoeven, and E. E. Hucke, Met. Soc. Conf. 7, 447 [1961].

45 A. Kvist and A. LundÉn, Z. Naturforsch. 19 a, 1058 [1964].

46 A. R. Allnatt and A. V. Chadwick, Trans. Faraday Soc. 62, 1726 [1966].

47 G. D. Rieck and D. L. Vogel, Acta Met. 14, 1703 [1966]. 
thermal diffusion is related to activation energies for diffusion. Further experiments as well as theoretical developments are required in order to give a satisfactory interpretation of thermal diffusion in solid sulfates.
This investigation is supported financially by "Statens Naturvetenskapliga Forskningsråd" and "Wilhelm och Martina Lundgrens Vetenskapsfond". We are indebted to Mrs. U. Blume and Mrs. L. Jansen for performing the chemical analysis, and to Dr. A. Kvist for stimulating discussions.

\title{
Viskosimetrische Untersuchungen zum Schmelzprozeß von Metallen am Beispiel des Galliums und der intermetallischen Verbindung $\mathrm{Hg}_{5} \mathrm{Tl}_{2}$
}

\author{
B. Predel und I. Arpshofen \\ Institut für Metallforschung der Universität Münster (Westf.) \\ (Z. Naturforsch. 23 a, 2052-2062 [1968] ; eingegangen am 18. August 1968)
}

\begin{abstract}
Zur viskosimetrischen Verfolgung des Schmelzvorganges von Metallen wurde ein Schwingtiegelviskosimeter konstruiert, das es gestattet, die Viskosität von Schmelzen, die frisch aus dem Festkörper entstanden sind, rasch und präzise zu messen. An hochreinem Gallium konnte ein viskosimetrischer Nachschmelzeffekt festgestellt werden, der darin besteht, daß die Viskosität der unmittelbar aus dem Kristall entstandenen Schmelze anomal hoch ist und innerehalb von etwa 1 min auf den üblichen Viskositätswert der Gleichgewichtsschmelze abfällt. Das Abklingen der überschüssigen Viskosität ist irreversibel. Beim Abkühlen des flüssigen Galliums bis unter seinen Schmelzpunkt tritt kein anomaler Anstieg der Viskosität ein. In ähnlicher Weise ist auch das Schmelzverhalten der Verbindung $\mathrm{Hg}_{5} \mathrm{Tl}_{2}$ untersucht worden. Hier tritt kein Nachschmelzeffekt auf.

Das unterschiedliche Verhalten der beiden untersuchten Substanzen ist auf die individuellen Änderungen der Bindungs- und Strukturverhältnisse beim Übergang fest-flüssig zurückzuführen. Beim Gallium treten am Schmelzpunkt unmittelbar nach der Auflösung des Gitters offenbar größere, nicht im Gleichgewicht befindliche Agglomerate auf. Erst nach deren Dissoziation ist die Gleichgewichtsstruktur der Schmelze erreicht. Unter idealisierenden Annahmen kann aus der Viskositätsüberhöhung beim Nachschmelzeffekt ein Clusteranteil an der Gesamtschmelze von größenordnungsmäßig $10 \%$ abgeschätzt werden.
\end{abstract}

Im Gegensatz zum atomaren Aufbau fester Metalle weisen Metallschmelzen keine sich über große Bereiche erstreckende Fernordnung und keine Formstabilität auf. Sie sind bekanntlich auch nicht völlig strukturlos wie die regellose Verteilung der Moleküle eines idealen Gases. Vielmehr zeigen sie eine Nahordnung, die darin besteht, daß sich in der Umgebung eines herausgegriffenen Flüssigkeitsatoms in einer bestimmten Entfernung im zeitlichen Mittel eine bestimmte Anzahl anderer Atome aufhält. Diesem statistisch-dynamischen Flüssigkeitsmodell kann man eine Auffassung an die Seite stellen, die die Flüssigkeit in der Umgebung eines herausgegriffenen Atoms als ein etwas verwackeltes Kristallgitter ansieht. Für das Vorhandensein der Nahordnung in der Flüssigkeitsstruktur liefern Röntgenbeugungsuntersuchungen den experimentellen Beweis (vgl. z. B. Hosemann und Bagchi ${ }^{1}$ ).

Es liegt nahe, danach zu fragen, wie der Schmelzprozeß interpretiert werden $\mathrm{kann}$, in welchem $\mathrm{Zu}$ -

1 R. Hosemann u. S. N. BAGCHI, Direct Analysis of Diffraction by Matter, North-Holland Publishing Comp., Amsterdam 1962 . sammenhang die Struktur der Schmelze mit der des Festkörpers steht und welche Zwischenstadien beim Schmelzen durchlaufen werden. Vom thermodynamischen Standpunkt aus interessiert die Frage, ob es sich beim Schmelzvorgang tatsächlich um einen Prozeß erster Ordnung handelt, der in streng reversibler Weise über Gleichgewichtszustände verläuft oder ob etwa auftretende Übergangsstrukturen zwischen fest und flüssig Ungleichgewichtsphasen darstellen, die in einem irreversiblen Prozeß in die Gleichgewichtsschmelze übergehen.

Anhaltspunkte für die Existenz von Zwischenzuständen mit merklicher Lebensdauer sind bekannt. Erwähnt sei der sog. Nachschmelzeffekt. Wie bereits früher eingehend beschrieben ${ }^{2}$, zeigt dieser Effekt an, daß im Anschluß an den eigentlichen Schmelzprozeß eine Reaktion abläuft, die mit einer deutlichen Enthalpieänderung verbunden ist. Diese Erscheinung, die bei Halbmetallen wie Antimon oder Wismut besonders stark ausgeprägt ist, kann als

2 B. Predel, Z. Metallkde. 54, 206 [1963]. 